\title{
Evaluation of Some Biochemical Parameters and Brain Oxidative Stress in Experimental Rats Exposed Chronically to Silver Nitrate and the Protective Role of Vitamin E and Selenium
}

\author{
Mouna Gueroui and Zine Kechrid \\ Laboratory of Applied Biochemistry and Microbiology, Department of Biochemistry, \\ Science faculty, Badji Mokhtar University, BP 12 Sidi Amar, Annaba, Algeria
}

(Received March 28, 2016; Revised August 14, 2016; Accepted August 18, 2016)

\begin{abstract}
Due to undesirable hazardous interactions with biological systems, this investigation was undertaken to evaluate the effect of chronic exposure to silver on certain biochemical and some oxidative stress parameters with histopathological examination of brain, as well as the possible protective role of selenium and/or vitamin $\mathrm{E}$ as nutritional supplements. Thirty six male rats were divided into six groups of six each: the first group used as a control group. Group II given both vitamin E ( $400 \mathrm{mg} / \mathrm{kg}$ ) of diet and selenium (Se) $(1 \mathrm{mg} / \mathrm{L})$ in their drinking water. Group III given silver as silver nitrate $\left(\mathrm{AgNO}_{3}\right)(20 \mathrm{mg} / \mathrm{L})$. Group IV given vitamin $\mathrm{E}$ and $\mathrm{AgNO}_{3}$. Group $\mathrm{V}$ given both $\mathrm{AgNO}_{3}$ and selenium. Group VI given $\mathrm{AgNO}_{3}$, vitamin $\mathrm{E}$ and Se. The animals were in the same exposure conditions for 3 months. According to the results which have been obtained; there was an increase in serum lactate dehydrogenase (LDH), lipase activities and cholesterol level, a decrease in serum total protein, calcium and alkaline phosphatase (ALP) activity in Agintoxicated rats. Moreover, the findings showed that $\mathrm{Ag}^{+}$ions affected antioxidant defense system by decreasing superoxide dismutase (SOD) activity and increasing vitamin E concentration with a high level of malondialdehyde (MDA) in brain tissue. The histological examination also exhibited some nervous tissue alterations including hemorrhage and cytoplasm vacuolization. However, the co-administration of selenium and/or vitamin E ameliorated the biochemical parameters and restored the histological alterations. In conclusion, this study indicated that silver could cause harmful effects in animal body and these effects can be more toxic in high concentrations or prolonged time exposure to this metal. However, selenium and vitamin $\mathrm{E}$ act as powerful antioxidants which may exercise adverse effect against the toxicity of this metal.
\end{abstract}

Key words: Silver, Rats, Oxidative stress, Brain tissue, Vitamin E, Selenium

\section{INTRODUCTION}

Each year, thousands of new chemicals are released into the environment, a substantial proportion of which are likely to elicit developmental neurotoxicity. Recently, there has been an explosive increase in the use of silver $(\mathrm{Ag})$ in medical and consumer products, largely in the form of silver

Correspondence to: Zine Kechrid, Laboratory of Applied Biochemistry and Microbiology, Department of Biochemistry, Science faculty, Badji Mokhtar University, BP 12 Sidi Amar, 23000 Annaba, Algeria

E-mail: kechridzine@yahoo.fr

This is an Open-Access article distributed under the terms of the Creative Commons Attribution Non-Commercial License (http:// creativecommons.org/licenses/by-nc/3.0) which permits unrestricted non-commercial use, distribution, and reproduction in any medium, provided the original work is properly cited. nanoparticles, leading to a corresponding increase in human and ecosystem exposures $(1,2)$. Silver is considered toxic for humans, aquatic and terrestrial animals $(3,4)$. The cellular pathology and the molecular mechanisms involved in their toxicity in mammalian cells are largely unknown. The recommendations of the World Health Organization (WHO) permit maximal concentrations of $0.1 \mathrm{mg} / \mathrm{L}$ of silver ions in drinking water disinfection (5) and it is known that chronic exposure leads to argyria, a clinical entity characterized by gray-blue pigmentation of the skin and other body viscera (6). In addition some studies have examined the neurotoxicity effects of silver in experimental animal studies and human clinical reports. Ohbo et al. (7) have concluded that the seizures observed in an argyric patient were likely to be due to the presence of silver in the patient's central nervous system (CNS). Landas et al. (8) have observed the deposition of silver nitrate $\left(\mathrm{AgNO}_{3}\right)$ in circumventricular organs 
(CVO) and in paraventricular and supraoptic nuclei of hypothalamus, thus, Rungby and Danscher (9) have suggested that the hypoactivity of mice treated by Ag is due to an influence of silver upon the functional status of the CNS. Rungby et al. (10) have found that a direct administration of silver salts to neonatal rats results in damage to particularly vulnerable areas of brain, such as the hippocampus. The role of antioxidants like vitamin $\mathrm{E}$ and selenium (Se) is known to alleviate harmful effects associated with heavy metals (11). Moreover, Se is a component of several selenoproteins and selenoenzymes with essential biological functions (12). It has been widely recognized as an essential dietary component with numerous beneficial effects on health, namely by its pharmacotherapeutic efficacy against brain diseases (13). This trace element is known to antagonize the toxicity of silver ions (14).Vitamin E is a lipid-soluble chain-breaking antioxidant which protects, especially, biological membranes from lipid peroxidation (15). Deficiency of dietary vitamin $\mathrm{E}$ and selenium has been showed to induce a number of lesions in rats depending upon the degree of depletion (16). The functional interrelation ship between vitamin $\mathrm{E}$ and selenium has long been recognized (17). In view of the above considerations, the present study was carried out to estimate the toxicity of silver on animal body and to evaluate the efficacy of vitamin $\mathrm{E}$ and selenium to alleviate this toxicity by measuring some biological serum markers and oxidative stress markers including brain lipid peroxidation (LPO) and antioxidants parameters with brain histopathology examination.

\section{MATERIALS AND METHODS}

Chemicals. Silver nitrate $\left(\mathrm{AgNO}_{3}\right)$, sodium selenite $\left(\mathrm{Na}_{2} \mathrm{SeO}_{3}\right)$, vitamin $\mathrm{E}$ ( $\alpha$-tocopherol), CDNB (1-chloro- 2.4 dinitrobenzene), DTNB (5,5'dithio-bis-(2-nitrobenzoic acid)), GSH (reduced glutathione), GSSG (oxidized glutathione) and epinephrine bathophenanthroline and NADPH (nicotinamide adenine dinucleotidephosphate reduced form) were obtained from sigma Chemical Co. (St Louis, Saint-Quentin Fallavier, France) and all other chemicals used in the experiment were of analytical grade.

Experiment animals. All experiments were performed with 'Wistar' male rats weighing about 260 280 g, which were purchased from Pasteur Institute, Algiers, Algeria. The animals were kept under good ventilation and were maintained on standard diet and water throughout the experimental period. They were kept at $22 \pm 2^{\circ} \mathrm{C}$ with the $12 \mathrm{hr}$ light/dark cycle and $40 \%$ humidity. All animal experiments were carried out according to the National Institute of Health Guideline for animal care and approved by the Ethics Committee of our institution. After two weeks of adaptation, thirty six rats were randomly divided into six groups of six each. Group I fed standard diet and used as control group. Group
II received vitamin $\mathrm{E}$ at a dose of $400 \mathrm{mg} / \mathrm{Kg}$ diet and selenium $(1 \mathrm{mg} / \mathrm{L})$ in their drinking water. Group III received $\mathrm{AgNO}_{3}$ in their drinking water $(20 \mathrm{mg} / \mathrm{L})$. Group IV given both $\mathrm{AgNO}_{3}(20 \mathrm{mg} / \mathrm{L})$ and standard diet enriched with vitamin E (400 mg/kg). Group V received $\mathrm{AgNO}_{3}(20 \mathrm{mg} /$ L) and selenium $(1 \mathrm{mg} / \mathrm{L})$. Group VI given $\mathrm{AgNO}_{3}$, vitamin $\mathrm{E}$ and Selenium. During the course of treatment, body weight gain, food intake and water consumption were recorded regularly. The doses of $\mathrm{AgNO}_{3}$ and the period of treatment were basically selected on previous study of Environmental Protection Agency (EPA) (18). Vitamin E and selenium doses were also chosen on the clinical application and on results from previous investigations of Kim et al. (19) and Qingzhi et al. (20) respectively. The treatments of rats continued for a period of three months. At the end of the experiment, animals were sacrificed by cervical decapitation without anesthesia to avoid animals stress, blood was transferred into non-heparinised tubes. Serum was obtained by centrifugation of the blood at $3000 \mathrm{rpm}$ and then quickly frozen at $-20^{\circ} \mathrm{C}$ for biochemical analysis. Brain samples were rapidly excised, rinsed in ice cold saline $[0.9 \%(\mathrm{w} / \mathrm{v})$ $\mathrm{NaCl}$. Then, one lobe of brain was homogenized in a twice volume of ice cold TBS (50 mM TRIS, $150 \mathrm{mM} \mathrm{NaCl}, \mathrm{pH}$ 7.4), the homogenates were centrifuged at $10.000 \mathrm{~g}$ for $15 \mathrm{~min}$ at $4^{\circ} \mathrm{C}$, and the resultant supernatant was frozen at $-20^{\circ} \mathrm{C}$ for oxidative parameters analysis. The other lobe of brain was fixed in formol solution and used for histological examination.

Biochemical analysis. Serum biochemical markers: glucose, transaminases (glutamic pyruvic transaminase: GPT, glutamic oxaloacetic transaminase: GOT), alkaline phosphatase (ALP), lactate dehydrogenase (LDH), direct bilirubin, total proteins, albumin, cholesterol, triglycerides, total lipids, creatinine, urea, uric acid, lipase, $\alpha$-Amylase, calcium, phosphor were assessed using Spinreact Laboratory Spain diagnostic kits using spectrophotometer (Jenway 6505, Jenway LTD, Essex, UK). The references were as follow: glucose-41011, GOT-1001161, GPT-1001171, ALP1001131, LDH-1001260, direct bilirubin-1001044, total proteins-100129, albumin-1001020, cholesterol-1001091, triglycerides-100131, total lipids-1001270, creatinine-1001110, urea-1001331, uric acid-1001010, lipase-1001275, $\alpha$-Amylase-41201, calcium-1001061, phosphor-1001150.

\section{Determination of oxidative parameters.}

Lipid peroxidation level: Lipid peroxidation as evidenced by formation of thiobarbituric acid reacting substances (TBARS), were measured by the method of Esterbauer and Cheeseman (21). 250 microliters of tissue homogenate were added to $1.5 \mathrm{~mL}$ of $1 \%$ phosphoric acid $(\mathrm{pH} 2.0)$ and $1 \mathrm{~mL}$ of $0.6 \%$ of TBA in air light tubes and the samples was cooled to room temperature and MDA (malondialdehyde)TBA was extracted with $2.5 \mathrm{~mL}$ of butanol. Organic phase 
was separated by centrifugation for $5 \mathrm{~min}$ at $2000 \mathrm{~g}$ and measured at $532 \mathrm{~nm}$. A 99\% TBARS are MDA, so TBARS concentration of the samples were calculated using the extinction coefficient of MDA is $1.56 \times 10^{5} \mathrm{M}^{-1} \mathrm{~cm}^{-1}$. Lipid peroxidation is expressed as nmol TBARS/mg prot.

Estimation of enzymatic antioxidants: The specific activity of brain superoxide dismutase (SOD) was determined according to the method described by Misra and Fridonich (22). $10 \mu \mathrm{L}$ of tissue homogenate were added to $970 \mu \mathrm{L}$ of ethylene diamine tetraacetic acid (EDTA) Sodium carbonate buffer $(0.05 \mathrm{M})$ at $\mathrm{pH} 10.2$. The reaction was started by adding $20 \mu \mathrm{L}$ of epinephrine $(30 \mathrm{mM})$ and the activity was measured at $480 \mathrm{~nm}$ for $4 \mathrm{~min}$. A unit of SOD is defined as the amount of enzyme that inhibits by $50 \%$ the speed of oxidation of epinephrine and the results were expressed as UI/mg protein.

Glutathione peroxidase (GSH-Px) catalyzes the reduction of hydroperoxides by utilizing GSH as a reductant. Determination of tissue GSH-Px activity was carried out according to the method of Flohe and Gunzler (23). The reaction mixture contained $0.2 \mathrm{~mL}$ of TBS (Tris $50 \mathrm{mM}$, $\mathrm{NaCl} 150 \mathrm{mM}$, pH 7.4); $0.4 \mathrm{~mL}$ of GSH (0.1 mM), $0.2 \mathrm{~mL}$ of homogenate was added and allowed to equilibrate for $5 \mathrm{~min}$ at $25^{\circ} \mathrm{C}$. The reaction was initiated by adding $0.2 \mathrm{~mL}$ of $\mathrm{H}_{2} \mathrm{O}_{2}(1.3 \mathrm{mM})$; reaction was terminated by addition of $1 \mathrm{~mL}$ of $1 \%$ Trichloroacetic acid (TCA). Tubes were centrifuged at $1500 \mathrm{~g}$ for $5 \mathrm{~min}$ and the supernatant was collected. To $0.48 \mathrm{~mL}$ of resultant supernatant, $2.2 \mathrm{~mL}$ of TBS (pH 7.4) and $0.32 \mathrm{~mL}$ of DTNB (1.0 mM) were added. After mixing, absorbance was recorded at $412 \mathrm{~nm}$ and the specific activity of this enzyme is expressed as $\mu \mathrm{mol} \mathrm{GSH} / \mathrm{mg}$ protein.

Glutathione-S-transferase (GST) activity of tissues was measured spectrophotometrically by the method of Habig et al. (24) using CDNB as electrophilic substrate that binds to GSH with the participation of the enzyme and forms a colored GSH-substrate complex, detected at $340 \mathrm{~nm}$. The activity of GST was expressed in terms of $\mu \mathrm{mol}$ CDNBGSH conjugate formed $/ \mathrm{min} / \mathrm{mg}$ protein.

Glutathione reductase (GR) activity was based on the method of Goldberg and Spooner (25). The enzymatic activity was assayed photometrically by measuring, NADPH consumption. In the presence of oxidized glutathione (GSSG) and NADPH, GR reduces GSSG and oxidizes NADPH, resulting in a decrease of absorbance at $340 \mathrm{~nm}$. Quantification was based on the molar extinction cœfficient of 6.22 $\mathrm{mM}^{-1} \mathrm{~cm}^{-1}$ of NADPH, 1 unit of GR was defined as the amount of enzyme that reduced $1 \mu \mathrm{mol}$ GSSG (corresponding to the consumption of $1 \mu \mathrm{mol}$ of NADPH) per minute at $25^{\circ} \mathrm{C}$. The GR activities were expressed as 1 unit per milligram protein.

Catalase activity (CAT) measured using the method of Sinha (26). It is based on the fact that dichromate in acetic acid is reduced to chromic acetate when heated in the presence of $\mathrm{H}_{2} \mathrm{O}_{2}$, with the formation of perchromic acid as an unstable intermediate. The chromic acetate thus produced is measured calorimetrically at $570 \sim 610 \mathrm{~nm}$. Since dichromate has no absorbance in this region, the presence of the compound in the assay mixture does not interfere at all with the colorimetric determination of chromic acetate. The catalase preparation is allowed to split $\mathrm{H}_{2} \mathrm{O}_{2}$ for different periods of time. The reaction is stopped at a particular time by the addition of dichromate/acetic acid mixture and the remaining $\mathrm{H}_{2} \mathrm{O}_{2}$ is determined by measuring chromic acetate calorimetrically after heating the reaction mixture.

Non-enzymatic antioxidants measurement. GSH concentration was performed with the method described by Ellman (27) based on the development of a yellow color when DTNB is added to compounds containing sulfhydryl groups. In brief, $0.8 \mathrm{~mL}$ of tissue homogenate was added to $0.2 \mathrm{~mL}$ of $0.25 \%$ sulphosalylic acid and tubes were centrifuged at $2500 \mathrm{~g}$ for $15 \mathrm{~min}$. Supernatant $(0.5 \mathrm{~mL})$ was mixed with $0.025 \mathrm{~mL}$ of $0.01 \mathrm{M}$ DTNB and $1 \mathrm{~mL} \mathrm{TBS}(\mathrm{pH}$ 7.4). Finally, absorbance at $412 \mathrm{~nm}$ was recorded. Total GSH content was expressed as nmol GSH/mg prot.

Vitamin E estimated by the method of Desai (28), to $1 \mathrm{~mL}$ of tissue homogenate, $1 \mathrm{~mL}$ of ethanol and $3 \mathrm{~mL}$ of petroleum ether were added, shaken rapidly and centrifuged at $4000 \mathrm{rpm}$ for $10 \mathrm{~min}, 2 \mathrm{~mL}$ of supernatant was evaporated to dryness at $80^{\circ} \mathrm{C}$, to that added $0.2 \mathrm{~mL}$ of bathophenanthroline, $0.2 \mathrm{~mL}$ of ferric chloride and $0.2 \mathrm{~mL}$ of phosphoric acid kept in dark for $5 \mathrm{~min}$ and then complete with $3 \mathrm{~mL}$ ethanol. The color developed was read at $530 \mathrm{~nm}$, vitamin $\mathrm{E}$ levels were expressed as $\mathrm{mg}$ vitamin $\mathrm{E} / \mathrm{mg}$ protein.

Protein determination. The protein content of tissue samples were measured by the method of Bradford (29) using bovine serum albumin as a standard.

Histological studies. For histological examination, brain was dissected and immediately fixed in formalin solution for $24 \mathrm{hr}$, processed by using a graded ethanol series, and then embedded in paraffin. The paraffin sections were cut into $5 \mu \mathrm{m}$ thick slices and stained with hematoxylin and eosin for light microscopic examination (30). The sections were then viewed and photographed.

Statistical analysis. All the results were expressed as mean values \pm SEM. Comparisons between the groups were performed by one-way ANOVA followed by student's $t$ test. Differences were considered significant at $p<0.05$.

\section{RESULTS}

Effect of treatments on body weight, food intake, water consumption and relative brain weight. $\mathrm{AgNO}_{3}$ dose $(20 \mathrm{mg} / \mathrm{L})$ did not affect clinical appearance, all animals survived until the termination of the study. It was 
Table 1. Body weight gain, relative brain weight, food intake and water consumption of control and experimental rats

\begin{tabular}{lcccccc}
\hline \hline Treatments & $\begin{array}{c}\text { Control } \\
(\mathrm{n}=6)\end{array}$ & $\begin{array}{c}\text { vit } \mathrm{E}+\mathrm{Se} \\
(\mathrm{n}=6)\end{array}$ & $\begin{array}{c}\mathrm{AgNO}_{3} \\
(\mathrm{n}=6)\end{array}$ & $\begin{array}{c}\mathrm{AgNO}_{3}+\text { vit E } \\
(\mathrm{n}=6)\end{array}$ & $\begin{array}{c}\mathrm{AgNO}_{3}+\mathrm{Se} \\
(\mathrm{n}=6)\end{array}$ & $\begin{array}{c}\mathrm{AgNO}_{3}+\mathrm{vit} \mathrm{E}+\mathrm{Se} \\
(\mathrm{n}=6)\end{array}$ \\
\hline Body weight gain $^{1}$ & $88.57 \pm 32.63$ & $80.71 \pm 20.34$ & $97.14 \pm 57.21$ & $75.72 \pm 51.12$ & $97.14 \pm 18.42$ & $66.71 \pm 47.97$ \\
Relative brain weight $^{2}$ & $0.33 \pm 0.05$ & $0.31 \pm 0.06$ & $0.33 \pm 0.07$ & $0.35 \pm 0.04$ & $0.33 \pm 0.01$ & $0.38 \pm 0.06$ \\
Food intake $^{3}$ & $21.22 \pm 2.02$ & $23.45 \pm 4.07$ & $23.5 \pm 4.21$ & $24.58 \pm 3.12$ & $25.47 \pm 1.69$ & $22.5 \pm 3.55$ \\
Water consumption $^{4}$ & $32.46 \pm 4.02$ & $30.06 \pm 5.10$ & $32.92 \pm 6.46$ & $32.38 \pm 4.05^{++}$ & $31.66 \pm 5.45$ & $30.05 \pm 4.62^{\#}$ \\
\hline
\end{tabular}

Values are means \pm SEM, $n$ : number of animals in each group.

${ }^{\#} p<0.05$ : significantly different from $\mathrm{AgNO}_{3},{ }^{++} p<0.01$ : statistical difference between $\mathrm{AgNO}_{3}+$ vit $\mathrm{E}$ and $\mathrm{AgNO}_{3}+\mathrm{vit} \mathrm{E}+\mathrm{Se}, \mathrm{Units:}{ }^{1} \mathrm{~g}$; ${ }^{2} \%$; ${ }^{3} \mathrm{~g} /$ rat/day; ${ }^{4} \mathrm{~mL} / \mathrm{rat} /$ day.

observed that $\mathrm{AgNO}_{3}$ had no effect on body weight gain and relative brain weight, food intake and water consumption (Table 1), except $\mathrm{AgNO}_{3}+$ vit $\mathrm{E}+\mathrm{Se}$ treated group showed significant decrease $(p<0.05)$ in water consumption as compared to $\mathrm{AgNO}_{3}$ exposed animals.

Effect of treatments on biochemical parameters. As seen from Table $2, \mathrm{AgNO}_{3}$ induced a significant increase $(p<0.05)$ in LDH and lipase activities, a significant decrease $(p<0.05)$ in ALP activity and calcium content, a highly significant increase $(p<0.01)$ in cholesterol and a highly significant decrease $(p<0.01)$ in total proteins compared to the corresponding control values. Supplementation of vitamin $\mathrm{E}$ and/or Se to $\mathrm{AgNO}_{3}$-treated group restored the levels of ALP, total protein, LDH and cholesterol, the two later parameters presented a remarkable decreases $(\mathrm{LDH}$ : $p<0.01, \mathrm{AgNO}_{3}+$ vit $\mathrm{E}+\mathrm{Se}$ and cholesterol: $p<0.001$,
$\mathrm{AgNO}_{3}+$ vit E, $\mathrm{AgNO}_{3}+$ vit $\left.\mathrm{E}+\mathrm{Se}, p<0.01, \mathrm{AgNO}_{3}+\mathrm{Se}\right)$ compared to metal exposed animals, while an amelioration in ALP activity $\left(p<0.01, \mathrm{AgNO}_{3}+\mathrm{Se}\right)$, and total protein concentration $\left(p<0.05, \mathrm{AgNO}_{3}+\right.$ vit E, $p<0.01, \mathrm{AgNO}_{3}+$ $\mathrm{Se})$ compared to $\mathrm{AgNO}_{3}$ group. In addition, total serum lipids were decreased in $\mathrm{AgNO}_{3}+$ vit $\mathrm{E}+$ Se group compared to $\mathrm{AgNO}_{3}(p<0.001), \mathrm{AgNO}_{3}+$ vit E $(p<0.01)$ and $\mathrm{AgNO}_{3}+$ $\operatorname{Se}(p<0.05)$.

\section{Effect of treatments on oxidative stress parameters.}

As shown in Fig. 1, exposure to $\mathrm{AgNO}_{3}$ produced a highly significant rise $(p<0.01)$ in TBARS levels in brain compared to control group. However, this parameter was reduced by vitamin $\mathrm{E}(p<0.05)$ or selenium $(p<0.01)$ supplementation compared to Ag-intoxicated group. Brain GSH content was not affected in Ag-exposure, while a very highly significant decrease $(p<0.001)$ in Se supplemented group

Table 2. Variation biochemical parameters in serum of control group and experimental rats

\begin{tabular}{|c|c|c|c|c|c|c|}
\hline Treatments & $\begin{array}{l}\text { Control } \\
(n=6)\end{array}$ & $\begin{array}{l}\text { vit } E+S e \\
\quad(n=6)\end{array}$ & $\begin{array}{l}\mathrm{AgNO}_{3} \\
(\mathrm{n}=6)\end{array}$ & $\begin{array}{c}\mathrm{AgNO}_{3}+\text { vit } \mathrm{E} \\
(\mathrm{n}=6)\end{array}$ & $\begin{array}{c}\mathrm{AgNO}_{3}+\mathrm{Se} \\
(\mathrm{n}=6)\end{array}$ & $\begin{array}{c}\mathrm{AgNO}_{3}+\text { vit } \mathrm{E}+\mathrm{Se} \\
(\mathrm{n}=6)\end{array}$ \\
\hline Glucose $^{1}$ & $0.13 \pm 0.02$ & $0.14 \pm 0.013$ & $0.13 \pm 0.01$ & $0.14 \pm 0.03$ & $0.15 \pm 0.022$ & $0.14 \pm 0.01$ \\
\hline $\mathrm{GOT}^{2}$ & $56.99 \pm 12.94$ & $76.05 \pm 12.05$ & $72.01 \pm 16.86$ & $66.20 \pm 21.50$ & $64.17 \pm 18.34$ & $72.92 \pm 10.24$ \\
\hline $\mathrm{GPT}^{2}$ & $34.22 \pm 16.57$ & $27.27 \pm 10.39$ & $36.70 \pm 16.74$ & $43.07 \pm 14.59$ & $36.55 \pm 9.12$ & $45.28 \pm 11.15$ \\
\hline $\mathrm{LDH}^{2}$ & $481.2 \pm 114.3$ & $411.23 \pm 113.8$ & $654.9 \pm 141.9^{*}$ & $436.9 \pm 156.1$ & $443.8 \pm 160.7$ & $370.2 \pm 141^{\# \#}$ \\
\hline $\mathrm{APL}^{2}$ & $93.06 \pm 28.65$ & $116.78 \pm 29.65$ & $58.85 \pm 17.73^{*}$ & $77 \pm 5.16$ & $101.7 \pm 34.85^{\mathrm{\# \#}}$ & $83.6 \pm 28.14$ \\
\hline Direct bilirubin ${ }^{1}$ & $2.08 \pm 0.68$ & $2.07 \pm 0.6$ & $2.08 \pm 0.87$ & $1.22 \pm 0.25^{++}$ & $2.12 \pm 0.53$ & $2.32 \pm 0.59$ \\
\hline Total proteins ${ }^{1}$ & $7.28 \pm 1.68$ & $6.46 \pm 0.87$ & $4.78 \pm 1.06^{* *}$ & $5.86 \pm 0.66^{\#}$ & $7.80 \pm 1.01^{\# \#++}$ & $5.2 \pm 0.41$ \\
\hline Albumin ${ }^{1}$ & $3.27 \pm 0.84$ & $2.94 \pm 0.97$ & $3.49 \pm 0.65$ & $3.14 \pm 0.33$ & $3.75 \pm 0.52$ & $3.14 \pm 0.9$ \\
\hline Cholesterol $^{3}$ & $1.86 \pm 0.62$ & $1.66 \pm 0.76$ & $3.12 \pm 0.62 * *$ & 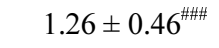 & $1.64 \pm 0.65^{\# \#}$ & $1.32 \pm 0.31^{\mathrm{mW}}$ \\
\hline Triglycerides $^{3}$ & $1.11 \pm 0.35$ & $1.20 \pm 0.48$ & $1.18 \pm 0.65$ & $1.23 \pm 0.13$ & $1.52 \pm 0.4$ & $1.26 \pm 0.4$ \\
\hline Total lipids ${ }^{4}$ & $262.59 \pm 71.2$ & $326.26 \pm 131.9$ & $341.67 \pm 55.4$ & $323.07 \pm 68.5^{++}$ & $323.77 \pm 29.4^{+}$ & $219.6 \pm 61.9^{\mathrm{\# \#}}$ \\
\hline Creatinine $^{4}$ & $0.69 \pm 0.29$ & $1.03 \pm 0.14$ & $1.015 \pm 0.24$ & $1.052 \pm 0.52$ & $0.86 \pm 0.23$ & $0.95 \pm 0.37$ \\
\hline Urea $^{4}$ & $35.2 \pm 11.53$ & $32.41 \pm 8.69$ & $33.33 \pm 5.42$ & $36.61 \pm 5.35$ & $37.21 \pm 6.42$ & $36.08 \pm 5.00$ \\
\hline Uric acid ${ }^{4}$ & $4.05 \pm 0.88$ & $4.73 \pm 0.89$ & $4.02 \pm 1.52$ & $4.45 \pm 1.26$ & $4.86 \pm 0.82$ & $4.22 \pm 1.44$ \\
\hline Lipase $^{2}$ & $179.43 \pm 46.4$ & $123.41 \pm 35.47$ & $247.7 \pm 39.5^{*}$ & $224.1 \pm 63.3$ & $221.43 \pm 64.8$ & $170.16 \pm 73.5$ \\
\hline$\alpha$-Amylase ${ }^{2}$ & $531.6 \pm 93.5$ & $622.62 \pm 95.93$ & $548.7 \pm 90.5$ & $537.1 \pm 49.7^{+}$ & $605.4 \pm 152.5$ & $635.8 \pm 95.5$ \\
\hline Calcium $^{4}$ & $11.95 \pm 1.24$ & $11.48 \pm 2.84$ & $9.73 \pm 2.46^{*}$ & $10.20 \pm 2.91$ & $11.56 \pm 2.94$ & $11.69 \pm 2.06$ \\
\hline Phosphor $^{4}$ & $7.73 \pm 1.81$ & $6.22 \pm 0.73$ & $6.25 \pm 0.80$ & $6.15 \pm 1.11$ & $6.28 \pm 1.19$ & $6.48 \pm 0.7$ \\
\hline
\end{tabular}

Values are means \pm SEM, $n$ : number of animals in each group.

${ }^{*} p<0.05,{ }^{* *} p<0.01$ : significantly different from control group, ${ }^{\#} p<0.05,{ }^{\# \#} p<0.01,{ }^{\# \# \#} p<0.001$ : significantly different from $\mathrm{AgNO}_{3},{ }^{+} p<0.05$, ${ }^{++} p<0.01$ : statistical difference between $\mathrm{AgNO}_{3}+$ vit $\mathrm{E}, \mathrm{AgNO}_{3}+\mathrm{Se}$ and $\mathrm{AgNO}_{3}+$ vit $\mathrm{E}+\mathrm{Se}$.

Units: ${ }^{1} \mathrm{~g} / \mathrm{dL} ;{ }^{2} \mathrm{U} / \mathrm{L} ;{ }^{3} \mathrm{mmol} / \mathrm{L} ;{ }^{4} \mathrm{mg} / \mathrm{dL}$. 


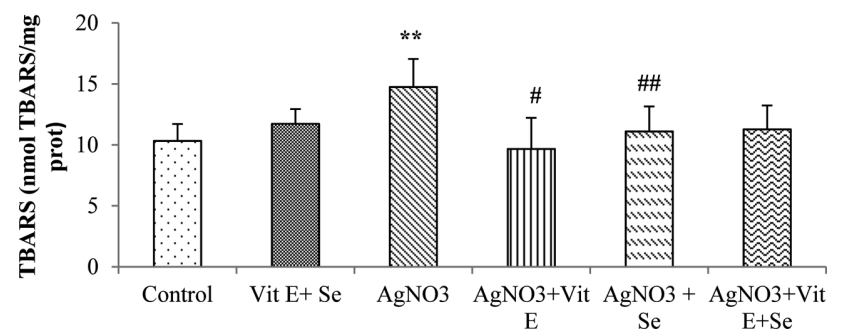

Fig. 1. Lipid peroxidation levels in brain tissue of control and experimental rats. ${ }^{*} p<0.01$ : significantly different from control group, ${ }^{*} p<0.05,{ }^{\# \#} p<0.01$ : significantly different from $\mathrm{AgNO}_{3}$.
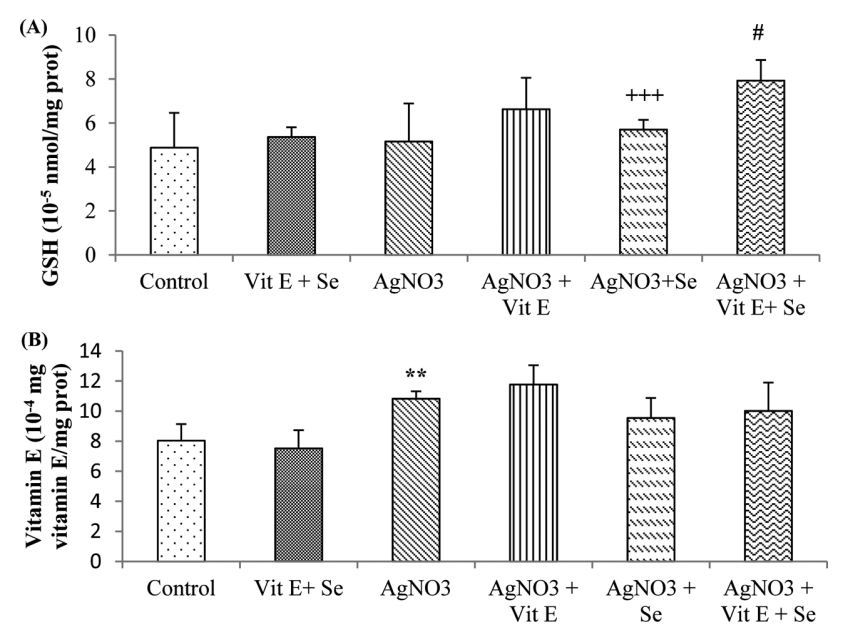

Fig. 2. Brain non-enzymatic antioxidant levels of control and experimental rats. (A) Reduced glutathione (GSH); (B) vitamin E. ${ }^{* *} p<0.01$ : significantly different from control group, ${ }^{*} p<0.05$ : significantly different from $\mathrm{AgNO}_{3},{ }^{+++} p<0.001$ : statistical difference between $\mathrm{AgNO}_{3}+$ vit $\mathrm{E}, \mathrm{AgNO}_{3}+\mathrm{Se}$ and $\mathrm{AgNO}_{3}+$ vit $\mathrm{E}+\mathrm{Se}$.

was observed in comparison to $\mathrm{AgNO}_{3}+$ vit $\mathrm{E}+$ Se treated animals. Meanwhile, the latter group presented a significant increase $(p<0.05)$ in GSH concentration compared to metal exposed rats (Fig. 2A). Furthermore, $\mathrm{AgNO}_{3}$ was found to increase brain vitamin E quantity $(p<0.01)$ (Fig. 2B). Data on GSH-Px, GST, GR, CAT and SOD activities are presented in Fig. 3 and 4. Brain GSH-Px, GR, GST and CAT activities were not altered under $\mathrm{AgNO}_{3}$. However, it was noted that silver caused a significant decline $(p<0.05)$ in SOD activity. Moreover, vitamin E treatment revealed a highly significant elevation $\left(p<0.01\right.$ : $\mathrm{AgNO}_{3}, p<0.01$ : $\mathrm{AgNO}_{3}+$ vit $\mathrm{E}+\mathrm{Se}$ ) in GSH-Px activity. Similarly this activity was increased by selenium treatment $(p<0.01$ : $\mathrm{AgNO}_{3}, p<0.05: \mathrm{AgNO}_{3}+$ vit $\left.\mathrm{E}+\mathrm{Se}\right)$. It was also observed that $\mathrm{Se}$ increased significantly $\left(p<0.05: \mathrm{AgNO}_{3}, \mathrm{AgNO}_{3}+\right.$ vit $\mathrm{E}+\mathrm{Se}) \mathrm{SOD}$ activity and decreased significantly $(p<$ 0.05: $\mathrm{AgNO}_{3}$ ) CAT activity.

Histological results. Upon histological examination of control rats and vitamin $\mathrm{E}+\mathrm{Se}$ treated rats, tissue presented
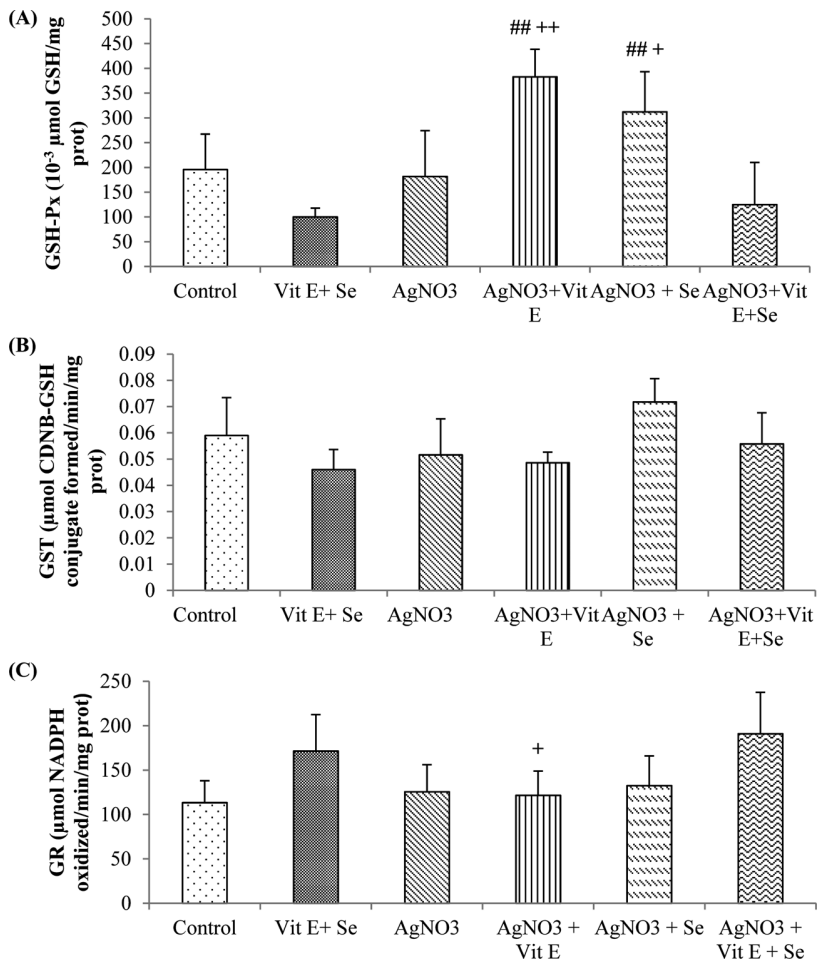

Fig. 3. Brain enzymatic antioxidant levels of control and experimental rats. (A) GSH-Px; (B) GST, C: GR. ${ }^{\# \#} p<0.01$ : statistical difference from $\mathrm{AgNO}_{3},{ }^{+} p<0.05,{ }^{++} p<0.01$ : statistical difference between $\mathrm{AgNO}_{3}$ + vit $\mathrm{E}, \mathrm{AgNO}_{3}+\mathrm{Se}$ and $\mathrm{AgNO}_{3}+$ vit $\mathrm{E}+\mathrm{Se}$.
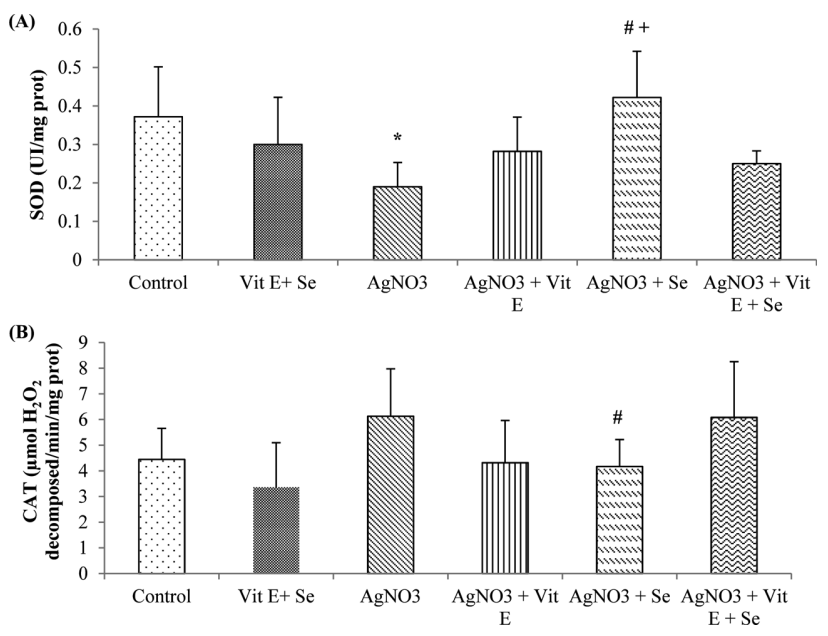

Fig. 4. Brain enzymatic antioxidant levels of control and experimental rats. (A) SOD, (B) CAT. ${ }^{*} p<0.05$ : significantly different from control group, ${ }^{\#} p<0.05$ : statistical difference from $\mathrm{AgNO}_{3},{ }^{+} p<$ 0.05: statistical difference between $\mathrm{AgNO}_{3}+$ vit $\mathrm{E}, \mathrm{AgNO}_{3}+\mathrm{Se}$ and $\mathrm{AgNO}_{3}+$ vit $\mathrm{E}+\mathrm{Se}$.

normal histoarchitecture (Fig. 5A, 5B). In the Ag-treated rats, histological sections showed abnormalities (Fig. 5C) when compared to controls. Histopathological changes were alleviated in the administration of vitamin $\mathrm{E}$ (Fig. 5D) or Se 


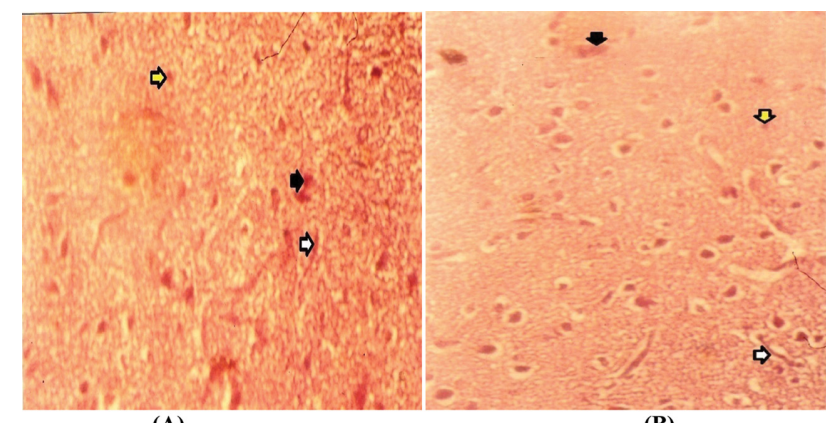

(A)

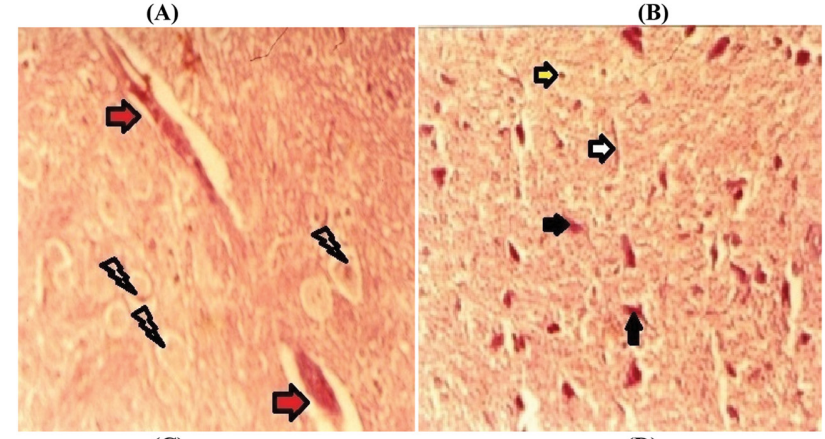

(C)

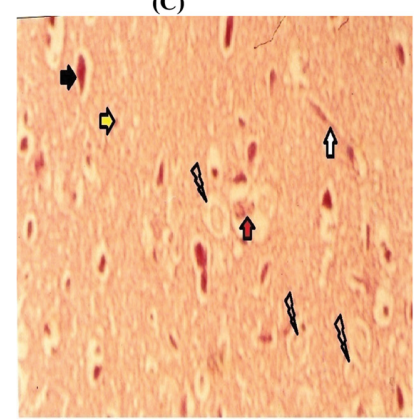

(E)

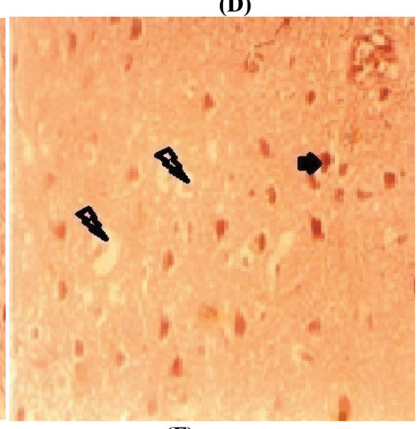

(F)

Fig. 5. Photographs showing histological changes in cerebral tissue in different groups; Control group (A); (Vit E + Se)-treated group (B), histological picture showed normal brain tissue; Agtreated group $(C)$ showed some abnormalities; nervous tissue exhibited hemorrhage, and vacuolated spaces in the affected area; $(\mathrm{Ag}+\mathrm{Vit} \mathrm{E})$-treated group (D), (Ag + Se)-treated group (E) and $(\mathrm{Ag}+\mathrm{Vit} \mathrm{E}+\mathrm{Se})$-treated group $(\mathrm{F})$ ameliorated brain tissue histological pictures with less vacuolated cytoplasm especially in vitamin E supplementation, histological damages significantly decreased. Optic microscopy section were stained using the haematoxylin-eosin method, 40x. neurons; glial cells; a net work of finely branching small blood vessels; hemorrhage; vacuolated cytoplasm.

(Fig. 5E), or both Se and vitamin E (Fig. 5F).

\section{DISCUSSION}

During three months of experiment, no clinical appearance or body weight loss have been observed after silver exposure. Also, relative brain weight, food intake and water consumption were not affected following oral administration of metal, these results were accentuated by some other

reports (31). Simultaneously, the treatment with selenium and/or vitamin E did not resulted any variations in body weight gain, relative brain weight and food intake except for a lower consumption of water in $\mathrm{AgNO}_{3}+$ vit $\mathrm{E}+\mathrm{Se}$ treated-group which could be a spurious finding and not an indication of toxicity effects. This study explored the influences of silver on some biochemical serum markers and oxidative stress status in brain. So that the findings showed an increases in LDH and lipase activities, cholesterol concentration and a decrease in ALP activity, total proteins and calcium in serum of $\mathrm{AgNO}_{3}$ rats. Increased levels of $\mathrm{LDH}$ could be attributed to liver disease, myocardial infarction, muscular dystrophy or augmentation of anaerobic respiration (32), the ALP is an enzyme which is presented in rat with high proportion in intestine, a decreased serum ALP may be due to hypothyroidism, hypoparathyroidism, malnutrition and/or gastrointestinal disease (33). Similarly to these results, some reports found an alteration in blood serum enzymes activities following oral administration of ionic silver or silver nanoparticles (34). Hypercholesterolemia might be resulted from hypothyroidism, hyperlipoproteinemia and/or liver toxicity (35). According to the later parameter, the rise in lipase activity may be due to adyslipidemia. However, the decrease in serum total protein of Agtreated rats might be due to changes in proteins synthesis and/or metabolism (36) and for the hypocalcaemia may be due to mal absorption or hypoparathyroidism (37). Corresponding to these findings, we could not discuss about hepatic damage without alterations in transaminase activity and direct bilirubin level, some studies have proven the toxic effects of silver on different organs including intestine, bone, thyroid and heart $(38,39)$. Meanwhile, animals treated with vitamin $\mathrm{E}$ and/or selenium presented lower blood LDH and cholesterol and higher ALP and total protein values than those of metal exposed animals, Calcium level and lipase activity are too normalized in these treatments, a findings which have also been observed by other reports (40). In the other side, data showed an increase in brain TBARS levels as biomarkers of lipid peroxidation, vitamin $\mathrm{E}$ content and a decrease in SOD activity. These results are correlated with our previous study which indicated a decline in SOD activity and an augmentation in vitamin $\mathrm{E}$ concentration in liver of $\mathrm{AgNO}_{3}$ intoxicated animals (41). Powers et al. (1) were also found that the longer exposure of neuronotypic PC12 cells to $\mathrm{AgNO}_{3}$ led to oxidative stress, loss of viability and reduced numbers of cells. Similarly, Hadrup et al. (42) was suggested that $\mathrm{Ag}^{+}$affected brain noradrenalin and dopamine in vivo and caused apoptotic death mechanisms in vitro. Moreover, under normal conditions, the brain is susceptible to oxidative damage due to its high oxygen consumption rate (in humans, the brain uses $\sim 20 \%$ of the circulating glucose, $20 \%$ of blood's oxygen and occupies $2 \%$ of the body weight), to high levels of polyunsaturated fatty acids (PUFA), and to a progressive accumulation of 
iron levels with aging $(13,43,44)$ and paradoxically its deficient oxidant defense mechanisms and its diminished cellular turn over (45). The antioxidant system (AOS) spans over a wide range of mechanisms such as enzymatic antioxidant system including SOD, GSH-Px and CAT to small molecular weight compounds such as vitamin E and GSH though in relatively low concentrations (44). The function of antioxidant systems is to modify the highly reactive oxygen species (ROS) to form less reactive intermediate which no longer pose a threat to the cell. These species can attack and damage all types of macromolecules (46); they are the main culprit for development of oxidative stress contributing to the development of cytotoxicity $(47,48)$. However, there must be a balance between oxidation and antioxidant's level in the system for healthy biological integrity to be maintained. Oxidants such as superoxide anions $\left(\mathrm{O}_{2}{ }^{\mathrm{o}-}\right)$, hydroxyl radical $\left(\mathrm{OH}^{\circ}\right)$, hydrogen peroxide $\left(\mathrm{H}_{2} \mathrm{O}_{2}\right)$, and singlet oxygen $\left({ }^{1} \mathrm{O}_{2}\right)$ may contribute to neuronal loss in cerebral ischemia and hemorrhage, and may be involved in the degeneration of neurons during normal aging and also in various diseases (49-51). In addition, the decrease in brain SOD activity could be explained by the investigation of Park et al. (51) who found that the major form of ROS generated by silver ions was the $\mathrm{O}_{2}{ }^{\circ-}, \mathrm{H}_{2} \mathrm{O}_{2}$ was not induced. Cortese Krott et al. (52) showed that $\mathrm{AgNO}_{3}$ increased the production of $\mathrm{O}_{2}{ }^{\mathrm{o}-}$ within mitochondria. Thus, it might be due to the reaction with $\mathrm{SH}$ groups of enzymes belonging to the respiratory chain (51-53). Whereas, the augmentation of brain vitamin $\mathrm{E}$ levels is corresponding to some transition metal as cadmium $(\mathrm{Cd})$ which increases the concentration of vitamin E in rat tissue (54). Van Der Zande et al. (55) have indicated that the silver content in blood was $2 \sim 3$ times lower than the silver content in brain; the authors have noticed the persistent of metal in this organ after two months of treatment. Evidence of silver transfer across the blood brain-barrier is alarming, but more researches are necessary.

Treatment with vitamin $\mathrm{E}$ and/or Se has appeared to reduce harmful effects in nervous tissue as demonstrated by our previous study (41) and by other investigators (13-15, 44). Therefore, vitamin $E$ has appeared to diminish free radicals in brain tissue. In contrast, it has ameliorated GSH-Px activity, the supplementation have also increased the cerebral content of this vitamin. Vitamin E may attenuate the toxic effects of ROS (13). It may also be a regulatory agent in intermediary metabolism, act synergistically as an antioxidant with GSH and ascorbate, and promote humoral antibody formation, because, it is not synthesized in the body and its concentration is dependent on the uptake (43). Its deficiency results mainly in neurological symptoms including impaired balance and coordination, injury to the sensory nerves, muscle weakness and damage to the retina of eye (13-43). In fact, selenium has diminished lipid peroxidation levels in brain, decreased CAT activity and increased
SOD and GSH-Px activities, this micronutrient accessed the central nervous system via cerebral capillary seleno-protein receptors and could be incorporated in newly synthesized selenoproteins. Se supplementation increased the activities of selenoproteins, by the high incorporation of selenocysteine in selenoproteins which may decrease free radical-mediated LPO and regenerate glutathione. This trace element reduces oxidative stress in cerebral ischemia, Alzheimer's and Parkinson's diseases (13-49). Under microscopic examination, distortions in cellular architecture were observed in brain tissue of Ag-treated rats. Neurodegenerative changes can be due to ROS (56). Vitamin E and selenium are able to restore or repair brain damages against the harmful effects of $\mathrm{Ag}$, but this restoration is clearer in vitamin $\mathrm{E}$ treated rats which is also supported by Yin et al. (57).

In conclusion, this study revealed that the contamination by silver is responsible for certain cellular disorders disturbing some blood and brain parameters, like xenobiotics, toxicity is depending on the dose and time of exposure. For that, an equilibrate diet rich in antioxidants is always requested.

\section{CONFLICT OF INTEREST}

Authors declare that no conflicts of interest.

\section{REFERENCES}

1. Powers, C.M., Wrench, N., Ryde, I.T., Smith, A.M., Seidler, F.J. and Slotkin, T.A. (2010) Silver impairs neurodevelopment: studies in PC12 cells. Environ. Health Perspect., 118, 73-79.

2. Lee, Y., Choi, J., Kim, P., Choi, K., Kim, S., Shon, W. and Park, K. (2012) A transfer of silver nanoparticles from pregnant rat to offspring. Toxicol. Res., 28, 139-141.

3. Roh, J.Y., Eom, H.J. and Choi, J. (2012) Involvement of caenohabditis elegans MAPK signaling pathways in oxidative stress response induced by silver nanoparticles exposure. Toxicol. Res., 28, 19-24.

4. Kwon, J.T., Minai-Tehrani, A., Hwang, S.K., Kim, J.E., Shin J.Y., Yu, K.N., Chang, S.H., Kim, D.S., Kwon, Y.T., Choi, I.J., Cheong, Y.H., Kim, J.S. and Cho, M.H. (2012) Acute pulmonary toxicity and body distribution of inhaled metallic silver nanoparticles. Toxicol. Res., 28, 25-31.

5. WHO (1996) Silver in drinking-water in Guidelines for drinking-water quality (2nd edition, Volume 2), World Health Organization, Geneva, pp. 338-343.

6. Holler, J.S., Fawler, B.A. and Nordberg, G.R. (2015) Handbook on the toxicology of metals: Silver (4th edition), Elsevier, pp. 1209-1216.

7. Ohbo, Y., Fukuzako, H., Takeuchi, K. and Takigawa, M. (1996) Argyria and convulsive seizures caused by ingestion of silver in a patient with schizophrenia. Psychiatry Clin. Neurosci., 50, 89-90.

8. Landas, S., Fischer, J., Wilkin, L.D., Mitchell, L.D., Johnson, A.K., Turner, J.W., Theriac, M. and Moore, K.C. (1985) Demonstration of regional blood-brain barrier permeability in human brain. Neurosci. Lett., 57, 251-256. 
9. Rungby, J. and Danscher, G. (1984) Hypoactivity in silver exposed mice. Acta Pharmacol. Toxicol. (Copenh.), 55, 398401.

10. Rungby, J., Slomianka, L., Danscher, G., Andersen, A.H. and West, M.J. (1987) A quantitative evaluation of the neurotoxic effect of silver on the volumes of the components of the developing rat hippocampus. Toxicology, 43, 261-268.

11. Serafín Muñoz, A.H., Wrobel, K., Gutierrez Corona, J.F. and Wrobel, K. (2007) The protective effect of selenium inorganic forms against cadmium and silver toxicity in mycelia of Pleurotus ostreatus. Mycol. Res., 111, 626-632.

12. Letavayová, L., Vlasáková, D., Spallholz, J.E., Brozmanová, J. and Chovanec, M. (2008) Toxicity and mutagenicity of selenium compounds in Saccharomyces cerevisiae. Mutat. Res., 638, 1-10.

13. Ben Amara, I., Soudani, N., Hakim, A., Troudi, A., Zeghal, K.M., Boudawara, T. and Zeghal, N. (2011) Selenium and vitamin $\mathrm{E}$, natural antioxidants, protect rat cerebral cortex against dimethoate-induced neurotoxicity. Pestic. Biochem. Physiol., 101, 165-174.

14. Peterson, R.P. and Jensen, L.S. (1972) Poult. Sci., 51, 1849.

15. Kabay, S.C., Ozden, H., Guven, G., Ustuner, M.C., Degirmenci, I., Olgun, E.G. and Unal, N. (2009) Protective effects of vitamin $\mathrm{E}$ on central nervous system in streptozotocininduced diabetic rats. Clin. Invest. Med., 32, E314-E321.

16. Chow, C.K. (1990) Effects of dietary vitamin $E$ and selenium on rats: pyruvate kinase, glutathione peroxidase and oxidative damage. Nutr. Res., 10, 183-194.

17. Chow, C.K. (1988) Interrelation ship of antioxidant defense systems in Cellular Antioxidant Defense Mechanisms, Vol. 2 (Chow, C.K. Ed.). CRC Press Inc., Boca Raton, pp. 217-237.

18. US Environmental Protection Agency (1980) Ambient water quality criteria for silver, Washington (EPA 440/5-80-071).

19. Kim, K.R., Kim, J.K. and Rhee, S.J. (2001) Effects of vitamin $\mathrm{E}$ on arachidonic acid cascade in platelets and aorta of acute cadmium-poisoned rats. Nutr. Res., 21, 657-665.

20. Wu, Q., Huang, K. and Xu, H. (2003) Effects of long-term selenium deficiency on glutathione peroxidase and thioredoxin reductase activities and expressions in rat aorta. $J$. Inorg. Biochem., 94, 301-306.

21. Esterbauer, H. and Cheeseman, K. (1990) Determination of aldehydic lipid peroxidation products: malonaldehyde and 4hydroxynonenal. Meth. Enzymol., 186, 407-421.

22. Misra, H.P. and Fridovich, I. (1977) Superoxide dismutase: "positive" spectrophotometric assays. Anal. Biochem., 79, 553-560.

23. Flohe, L. and Gunzler, W.A. (1984) Analysis of glutathione peroxidase. Meth. Enzymol., 105, 114-121.

24. Habig, W.H., Pabst, M.J. and Jakoby, W.B. (1974) Glutathione S-transferase. The first enzymatic step in mercapturic acid formation. J. Biol. Chem., 249, 7130-7139.

25. Goldberg, D.M. and Spooner, R.J. (1983) Methods of enzymatic analysis (Bergmeyen, H.V. Ed.). VerlogChemie, Deerfield Beach, pp. 258-265.

26. Sinha, A.K. (1972) Colorimetric assay of catalase. Anal. Biochem., 47, 389-394.

27. Ellman, G.L. (1959) Tissue sulfhydryl groups. Arch. Biochem. Biophys., 82, 70-77.

28. Desai, I.D. (1984) Vitamin E analysis method for animal tis- sue. Methods Enzymol., 105, 138-147.

29. Bradford, M.M. (1976) A rapid and sensitive method for the quantities of microgram quantities of protein utilizing the principle of protein binding. Anal. Biochem., 72, 248-254.

30. Hould, R. (1984) Techniques d'histopathologie et de cytopathologie. Ed Maloine., 19-21, 225-227.

31. Kim, Y.S., Song, M.Y., Park, J.D., Song, K.S., Ryu, H.R., Chung, Y.H., Chang, H.K., Lee, J.H., Oh, K.H., Kelman, B.J., Hwang, I.K. and Yu, I.J. (2010) Subchronic oral toxicity of silver nanoparticles. Part. Fibre Toxicol., 7, 20.

32. Burtis, C.A. and Ashwood, E.R. (1999) Tietz textbook of clinical chemistry (3rd edition), Saunders, Philadelphia.

33. Evans, G.O., O’Brien, P.J. and Watterson, C.L. (2009) Animal clinical chemistry, Taylor \& Francis Group, Boca Raton.

34. Kim, Y.S., Kim, J.S., Cho, H.S., Rha, D.S., Kim, J.M., Park, J.D., Choi, B.S., Lim, R., Chang, H.K., Chung, Y.H., Kwon, I.H., Jeong, J., Han, B.S. and Yu, I.J. (2008) Twenty-eight-day oral toxicity, genotoxicity, and gender related tissue distribution of silver nanoparticles in Sprague Dawley rats. Inhal. Toxicol., 20, 575-583.

35. Sung, J.H., Ji, J.H., Park, J.D., Yoon, J.U., Kim, D.S., Jeon, K.S., Song, M.Y., Jeong, J., Han, B.S., Han, J.H., Chung, Y.H., Chang, H.K., Lee, J.H., Cho, M.H., Kelman, B.J. and Yu, I.J. (2009) Subchronic inhalation toxicity of silver nanoparticles. Toxicol. Sci., 108, 452-61.

36. Das, K.K. and Dasgupta, S. (2000) Effect of nickel on testicular nucleic acid concentrations of rats on protein restriction. Biol. Trace Elem. Res., 73, 175-180.

37. Clarck, W.L., Balinski, E.L., Maie, S.S. and Zak, B. (1975) Spectrometric study of a direct determination of Serum Calcium. Microchem. J., 20, 22-32.

38. Olcott, C.T. (1950) Experimental argyrosis; hypertrophy of the left ventricle of the heart in rats ingesting silver salts. AMA Arch. Pathol., 49, 138-149.

39. Fung, M.C. and Bowen, D.L. (1996) Silver products for medical indications: risk-benefit assessment. J. Toxicol. Clin. Toxicol., 34, 119-126.

40. Chow, C.K. (1985) Vitamin E and blood. World Rev. Nutr. Diet., 45, 133-166.

41. Gueroui, M. and Kechrid, Z. (2015) Effect of the joint supplementation of vitamin $\mathrm{E}$ and selenium on chronic silver induced liver injury in male (wistar) albino rats. Int. J. Pharm. Sci. Rev. Res., 34, 176-182.

42. Hadrup, N., Loeschner, K., Mortensen, A., Sharma, A.K., Qvortrup, K., Larsen, E.H. and Lam, H.R. (2012) The similar neurotoxic effects of nanoparticulate and ionic silver in vivo and in vitro. Neurotoxicology, 33, 416-423.

43. Makar, T.K., Nedergaard, M., Preuss, A., Gelbard, A.S., Perumal, A.S. and Cooper, A.J. (1994) Vitamin E, ascorbate, glutathione, glutathione disulfide, and enzymes of glutathione metabolism in cultures of chick astrocytes and neurons: evidence that astrocytes play an important role in antioxidative processes in the brain. J. Neurochem., 62, 45-53.

44. Devi, S.A. and Kiran, T.R. (2004) Regional responses in antioxidant system to exercise training and dietary Vitamin $\mathrm{E}$ in aging rat brain. Neurobiol. Aging, 25, 501-508.

45. Ilhan, A., Gurel, A., Armutcu, F., Kamisli, S., Iraz, M., Akyol, O. and Ozen, S. (2004) Ginkgo biloba prevents mobile phoneinduced oxidative stress in rat brain. Clin. Chim. Acta, 340, 
153-162.

46. Lee, J. (2010) Use of antioxidants to prevent cyclosporine a toxicity. Toxicol. Res., 26, 163-170.

47. Nirwane, A., Sridhar, V. and Majumdar, A. (2016) Neurobehavioural changes and brain oxidative stress induced by acute exposure to GSM900 mobile phone radiations in Zebrafish (Danio rerio). Toxicol. Res., 32, 123-132.

48. Lee, J.G., Noh, W.J., Kim, H. and Lee M.Y. (2011) Generation of reactive oxygen species contributes to the development of carbon black cytotoxicity to vascular cells. Toxicol. Res., 27, 161-166.

49. Bourre, J.M., Dumonta, O., Cleament, M., Dinha, L., DroyLefaix, M.T. and Christen, Y. (2000) Vitamin E deficiency has different effects on brain and liver phospholipid hydroperoxide glutathione peroxidase activities in the rat. Neurosci. Lett., 286, 87-90.

50. Otitoju, O., Onwurah, I.N.E., Otitoju, G.T.O. and Ugwu, C.E. (2008) Oxidative stress and superoxide dismutase activity in brain of rats fed with diet containing permethrin. Biokemistri, 20, 93-98.

51. Park, H.J., Kim, J.Y., Ki, J., Lee, J.H., Hahn, J.S., Gu, M.B. and Yoon, J. (2009) Silver-ion-mediated reactive species generation affecting bactericidal activity. Water Res., 43, 10271032.

52. Cortese-Krott, M.M., Münchow, M., Pirev, E., Hebner, F., Bozkurt, A., Uciechowski, P., Pallua, N., Kröncke, K.D. and Suschek, C.V. (2009) Silver ions induce oxidative stress and intracellular zinc release in human skin fibroblasts. Free
Radic. Biol. Med., 47, 1570-1577.

53. Almofti, M.R., Ichikawa, T., Yamashita, K., Terada, H. and Shinohara, Y. (2003) Silver ion induces a cyclosporine ainsensitive permeability transition in rat liver mitochondria and release of apoptogenic cytochrome C. J. Biochem., 134, 43-49.

54. Ognjanovic, B.I., Pavlovic, S.Z., Maletic, S.D., Zikic, R.V., Stajn, A.S., Radojicic, R.M., Saicic, Z.S. and Petrovic, V.M. (2003) tective influence of vitamin E on antioxidant defense system in the blood of rats treated with cadmium. Physiol. Res., 52, 563-570.

55. van der Zande, M., Vanderbriel, R.J., Van Doren, E., Kramer, E., Herrera Rivera, Z., Serrano-Rojero, C.S., Gremmer, E.R., Mast, J., Peters, R.J., Hollman, P.C., Hendriksen, P.J., Marvin, H.J., Peijnenburg, A.A. and Bouwmeester, H. (2012) Distribution, elimination, and toxicity of silver nanoparticles and silver ions in rats after 28-day oral exposure. ACS Nano, 6, 7427-7442.

56. Liu, F., Mahmood, M., Xu, Y., Watanabe, F., Biris, A.S., Hansen, D.K., Inselman, A., Casciano, D., Patterson, T.A., Paule, M.G., Slikker, W. Jr. and Wang, C. (2015) ffects of silver nanoparticles on human and rat embryonic neural stem cells. Front. Neurosci., 9, 115.

57. Yin, N., Yao, X., Zhou, Q., Faiola, F. and Jiang G. (2015) Vitamin $\mathrm{E}$ attenuates silver nanoparticle-induced effects on body weight and neurotoxicity in rats. Biochem. Biophys. Res. Commun., 458, 405-410. 